\title{
Stephan Gollasch \\ Overview on introduced aquatic species in European navigational and adjacent waters
}

Received: 15 May 2005/ Accepted: 9 August 2005/Published online: 18 February 2006

(C) Springer-Verlag and AWI 2006

\begin{abstract}
More than 1,000 non-indigenous aquatic species have been recorded, in total, from coastal Europe, i.e. navigational inland waterways for ocean-going vessels and adjacent water bodies in close proximity. Regions considered in this overview range from European Arctic waters to the Mediterranean Sea and Irish waters to the Black Sea. The majority of introduced taxa have been first recorded since the 1950s. Approximately 600 taxa (ranging from unicellular algae to vertebrates) are established with self-sustaining populations. The dominating group of exotic species across all seas is zoobenthos organisms. Introduction vectors are predominantly shipping (ballast water and hull fouling) and species movements for aquaculture or stocking purposes.
\end{abstract}

Keywords Introduced species - Transport vector · Ballast water $\cdot$ Hull fouling $\cdot$ Aquaculture

\section{Introduction}

Non-indigenous aquatic species are of primary concern to many regulating authorities and are seen as one of the top four anthropogenic threats of the worlds' oceans. Intentional and accidental species introductions have often resulted in their establishment outside the native ranges. Introduced species have the potential to alter environments and may cause the loss of earnings (Cohen and Carlton 1995). It is generally assumed that the key introduction vectors are unintentional transport by ships and intentional importations of aquaculture target species as well as accidental releases from aquaculture sites.

Communicated by K. Reise

S. Gollasch

GoConsult, Bahrenfelder Str. 73a, 22765 Hamburg,

Germany

E-mail: sgollasch@aol.com

Tel.: + 49-40-3905460

Fax: + 49-40-3603094767
Stocking initiatives also contributed considerably (Carlton 1985, 1987; Sindermann 1992; Eno 1996; Eno et al. 1997; Reise et al. 1999).

Overviews on introduced species exist for some European Seas: North Sea (Gollasch 1996; Reise et al. 1999; Nehring 2002), Baltic Sea (Leppäkoski 1994; Gollasch and Mecke 1996; Leppäkoski and Olenin 2000; Olenin et al. 2005), British Isles (Eno 1996; Eno et al. 1997), Ireland (Minchin and Eno 2002), Mediterranean Sea (Galil and Zenetos 2002; CIESM 2005). Other regions, such as the Atlantic seaboard of Europe are not well studied. The objectives of this study are to (a) prepare an inventory of non-indigenous species in all navigational coastal European waters and adjacent water bodies in close proximity, (b) study the relationship of established non-native species versus species only known to occur occasionally and (c) assess the relative importance of invasion vectors. Limno-terrestric mammals and birds, such as the musk rat and Canada goose, were not considered here.

\section{Methods}

This inventory is based on a comprehensive literature research (see references above). A key publication reviewed was the summary of marine introduced species in Europe (Streftaris et al. 2005 and references therein). Publications in scientific journals as well as "grey literature", such as meeting reports of international working groups, have been consulted. In addition the Internet was searched for relevant databases from July 2004 to January 2005.

Habitats considered were the European coastal waters, inland navigational waterways of ocean-going vessels and adjacent inland waters in close proximity. This limitation was chosen because shipping is the dominating introduction vector in coastal Europe. In waters in close proximity to coastal regions other introduction vectors, such as stocking and species introductions for aquaculture purposes, may be dominating. Considering 
marine coastal waters only delivers a biased picture, as many of the busiest ports in Europe, i.e. ballast water discharge zones, are located in brackish and freshwater habitats in inner estuaries (e.g. the ports of Antwerp, Rotterdam and Hamburg). In addition navigational canals for ocean-going vessels, such as the Kiel Canal, were included to deliver a more comprehensive inventory of introduced species. Adjacent freshwater bodies such as lakes and rivers in close proximity to the abovementioned waters were also considered.

The geographic coverage stretches from the Arctic in the North to the southeastern Mediterranean Sea. The most western part considered is the west coast of Ireland and the easternmost region the Black Sea. Atlantic Europe and the Azores as well as the Canary Islands were also included.

\section{Results}

\section{Species}

In total 1,032 non-indigenous species have been found in European coastal and adjacent waters of which 594 species $(57.6 \%)$ are assumed to occur in self-sustaining populations. Of all non-indigenous species found, the majority are zoobenthic invertebrates (563 taxa), primarily crustaceans, molluscs, polychaetes and hydroids. Fish with 189 records and phytobenthos species with 172 records also considerably contribute to the total number of introduced species in Europe. In phytobenthos seven species of marshland vegetation or submerged plants are included. Introduced macroalgae are mostly red and brown algae. With 54 taxa phytoplankton species are also frequently recorded (Table 1).

At least 32 species are considered to be cryptogenic, i.e. it is unknown whether they are native or introduced. However, this number is assumed to increase as the invasion status of many species remains unknown. Other taxa not yet determined to species level have been excluded from this list, but may also contribute to the number of cryptogenic species.

Most introduced species are found in a locally limited distribution. A total of 777 taxa are known from one

Table 1 Non-indigenous species (total and established species) in European coastal waters according to life forms

\begin{tabular}{lcclc}
\hline Group & $\begin{array}{l}\text { Number } \\
\text { of all } \\
\text { species }\end{array}$ & $\begin{array}{l}\text { Percent } \\
\text { of all } \\
\text { species }\end{array}$ & $\begin{array}{l}\text { Number } \\
\text { of established } \\
\text { species }\end{array}$ & $\begin{array}{l}\text { Percent } \\
\text { of established } \\
\text { species }\end{array}$ \\
\hline Zoobenthos & 563 & 54.6 & 309 & 52.0 \\
Fish & 189 & 18.3 & 58 & 9.8 \\
Phytobenthos & 172 & 16.7 & 152 & 25.6 \\
Phytoplankton & 54 & 5.2 & 38 & 6.4 \\
Zooplankton & 40 & 3.9 & 26 & 4.4 \\
Other & 14 & 1.3 & 11 & 1.8 \\
Total & 1,032 & 100.0 & 594 & 100.0 \\
\hline
\end{tabular}

Other $=$ parasites, pathogens and fungi
Table 2 Non-indigenous (established, unestablished and cryptogenic) taxa according to the number of European coastal regions including adjacent wasters (see Table 3)

\begin{tabular}{lcc}
\hline $\begin{array}{l}\text { Number of regions } \\
\text { invaded }\end{array}$ & $\begin{array}{l}\text { Number of } \\
\text { invaders }\end{array}$ & Percentage \\
\hline 1 & 777 & 75.3 \\
2 & 142 & 13.8 \\
3 & 57 & 5.5 \\
4 & 22 & 2.1 \\
5 & 12 & 1.2 \\
6 & 15 & 1.4 \\
7 & 4 & 0.4 \\
8 & 3 & 0.3 \\
Total & 1,032 & 100.0 \\
\hline
\end{tabular}

region and 142 from two (Table 2). However, three species are very common and can be found in all European Seas: Mya arenaria, Crassostrea gigas and Bonnemaisonia hamifera. Also widespread, occurring in seven of the eight regions considered, are Teredo navalis, Oncorhynchus mykiss, Ficopomatus enigmaticus and Balanus improvisus.

\section{Regions}

The regional invasion pattern in European seas is very different. The highest number of introduced species was found in the Mediterranean Sea (662 taxa of which 325 are considered to be established). The lowest number of invaders is documented from European Arctic waters (18 species) (Table 3 ).

In percent of all introduced species the Mediterranean Sea hosts most taxa with $46.8 \%$ followed by the North Sea with $16.2 \%$. The lowest number of invaders of the seas considered is found in the European Arctic waters $(1.3 \%$ of all non-indigenous species found) (Table 3$)$.

\section{Vectors}

In many cases the introduction vector cannot clearly be identified, as cirripeds for example may be introduced in the ballast water, hull fouling of ships or as fouling organisms on bivalves being imported as target species for aquaculture activities. In case one vector could not be clearly identified, all possible vectors have been noted. For nine species it was impossible to assess the introducing vector (Table 4).

The dominating invasion "vector" attributed to 253 taxa $(24.5 \%)$ is the opening of the Suez Canal (also known as Lessepsian migration; Ferdinand de Lesseps planned the Suez Canal which opened in 1869) (B. Galil, in preparation). However, this is not considered to be a vector; it is rather a removal of a migration barrier. As many species migrated through the canal it was included here for reasons of comparison (Table 4). Lessepsian migrants included here (established, unestablished and 
Table 3 Invasion status of introduced species according to the European Seas considered (including adjacent waters)

\begin{tabular}{|c|c|c|c|c|c|c|c|}
\hline Region & $\begin{array}{l}\text { Number of } \\
\text { established } \\
\text { species }\end{array}$ & $\begin{array}{l}\text { Number of } \\
\text { unestablished } \\
\text { species }\end{array}$ & $\begin{array}{l}\text { Number of } \\
\text { cryptogenic } \\
\text { species }\end{array}$ & $\begin{array}{l}\text { Number of } \\
\text { extinct species }\end{array}$ & $\begin{array}{l}\text { Number of species } \\
\text { with unknown } \\
\text { invasion status }\end{array}$ & Total number & Total percent \\
\hline Mediterranean Sea & 325 & 116 & 23 & No data & 198 & 662 & 46.8 \\
\hline North Sea & 144 & 9 & 16 & 4 & 57 & 230 & 16.2 \\
\hline Atlantic coast & 112 & 19 & 5 & 2 & 39 & 177 & 12.5 \\
\hline Baltic Sea & 99 & 1 & 15 & 5 & 50 & 170 & 12.0 \\
\hline Black Sea & 61 & 9 & 3 & No data & 10 & 83 & 5.9 \\
\hline Azores & 24 & No data & No data & No data & 1 & 25 & 1.8 \\
\hline $\begin{array}{l}\text { Irish waters } \\
\text { and NW UK }\end{array}$ & 39 & 3 & 4 & No data & 5 & 51 & 3.6 \\
\hline Arctic waters & 10 & 1 & 1 & No data & 6 & 18 & 1.3 \\
\hline Total & 814 & 158 & 67 & 11 & 366 & 1,416 & 100.0 \\
\hline
\end{tabular}

The total number of taxa is higher as the total number of all introduced species in European Seas because several introduced species occur in more than one region (see Table 2)

cryptogenic species) have been found in the Mediterranean Sea but originate from the Red Sea and vice versa.

Combining ballast water (230 taxa) and hull fouling (170 taxa) shipping is the most prominent vector for species introductions to Europe (400 taxa). Aquaculture activities resulted in the intentional and unintentional introduction of 161 species. With 90 taxa, stocking is also an important means of introduction (Table 4).

\section{Salinity}

The vast majority of the introduced established taxa are either brackish or marine species (664 species) whereas 105 freshwater species have been found in the waters considered. It should be noted that for some regions data on introduced freshwater species are lacking possibly resulting in higher numbers once these data become available. In regions without larger freshwater bodies in close proximity to the coast, e.g. the Mediterranean Sea

Table 4 Absolute and relative importance of invasion vectors (all species, i.e. established, unestablished and cryptogenic taxa)

\begin{tabular}{lrr}
\hline Vectors & Taxa & Percent \\
\hline Lessepsian migration & 253 & 24.5 \\
Ballast water & 230 & 22.3 \\
Hull fouling & 170 & 16.5 \\
Aquaculture & 161 & 15.6 \\
Stocking & 90 & 8.7 \\
Range expansion & 65 & 6.3 \\
Ornamental & 20 & 1.9 \\
Canal (other than Suez) & 20 & 1.9 \\
Science & 8 & 0.8 \\
Bait & 6 & 0.6 \\
Not assessable & 9 & 0.9 \\
Total & 1,032 & 100.0 \\
\hline
\end{tabular}

Lessepsian migration is the species movement through the Suez Canal. Range expansion refers to active and passive species dispersal. Aquaculture includes species not intended to be placed in open waters and refers to escapes from aquaculture facilities (target and non-target species). In contrast, stocking refers to taxa which have intentionally been released and the Atlantic seaboard of Europe, marine invaders are clearly dominating (Table 5).

\section{Timeline}

The introduced species with the longest history in European waters are $T$. navalis, $M$. arenaria and Cyprinus carpio, all being introduced prior to 1400 . Figure 1 shows the increasing number of first records of nonindigenous species in European coastal waters since 1750. It can clearly be seen that the number of new species records increases slightly since 1850 and more drastically since 1950 .

Almost all seas show an increasing trend in the invasion rate over time (Fig. 2). Considering the first recorded species since 1850 in the most invaded sea, the Mediterranean Sea, a new invader was found every 15.8 weeks. Since 1950 new occurring species were found here every 6.2 weeks indicating the increased invasion rate. However, in Irish and northwestern waters of the

Table 5 Non-indigenous established species excluding parasites and pathogens in European coastal waters according to salinity regime

\begin{tabular}{llrr}
\hline Region & \multicolumn{2}{l}{ Salinity regime } & \multirow{2}{*}{ Total } \\
\cline { 2 - 3 } & \multicolumn{2}{l}{ Freshwater } & Brackish and marine \\
\hline Mediterranean Sea & 10 & 307 & 317 \\
North Sea & 33 & 99 & 132 \\
Atlantic coast & 6 & 95 & 101 \\
Baltic Sea & 41 & 51 & 92 \\
Black Sea & 12 & 47 & 59 \\
Azores & No data & 24 & 24 \\
Irish waters and NW UK & 3 & 33 & 36 \\
Arctic waters & No data & 8 & 8 \\
Total & 105 & 664 & 769 \\
\hline
\end{tabular}

The total number of taxa is higher as the total number of all established introduced species in European Seas (see Table 1) because several introduced species occur in more than one region (see Table 2) 


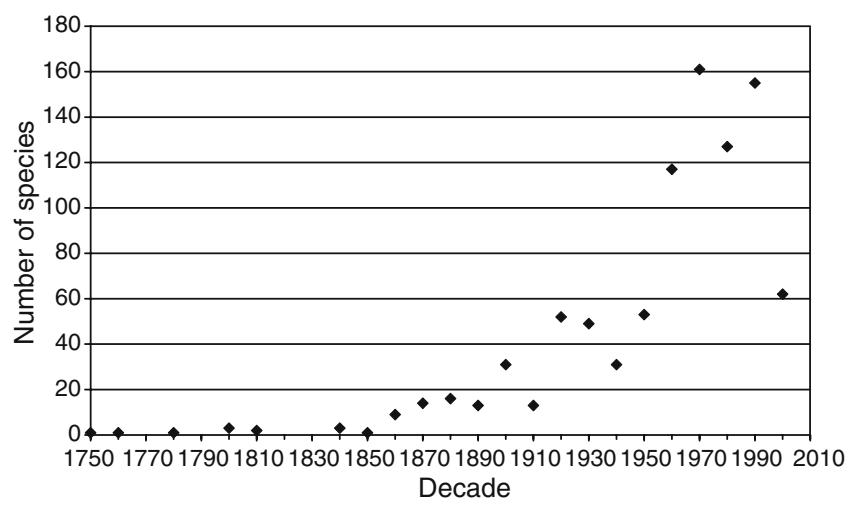

Fig. 1 First records of introduced (established, unestablished and cryptogenic) species in European Seas in decades since 1750

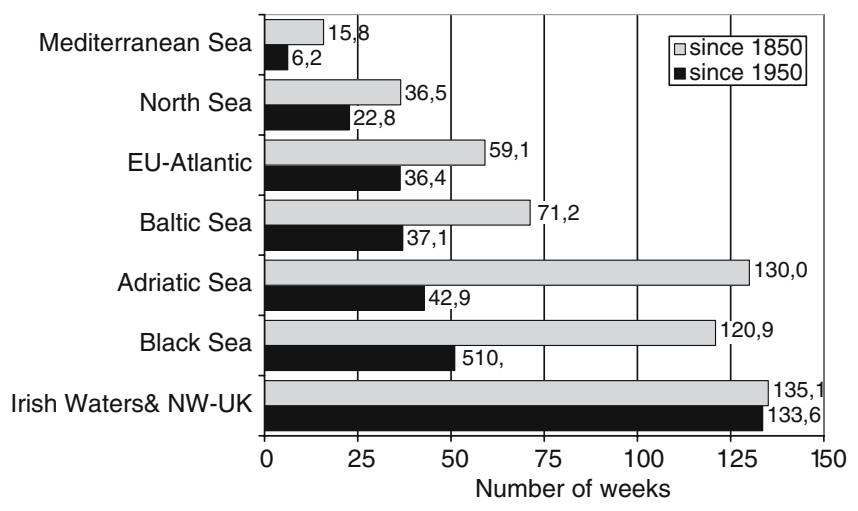

Fig. 2 Average time (in weeks) between first records of introduced (established, unestablished and cryptogenic) species in European coastal waters since 1850 (grey bars) and 1950 (black bars)

United Kingdom the invasion rate remains unchanged since 1850 .

\section{Discussion}

All non-indigenous species are potentially harmful unless it is proven that the risks involved are low. In rare cases the introduction of the species may even be considered beneficial as they may, e.g. pose a source for fishing (Olsvik 1996). However, the uncertainty of negative impacts associated with species invasions emphasises the need for a precautionary approach to minimize the unintentional transport of non-indigenous species.

Many of the 1,032 non-native species have been found in European coastal and adjacent waters and some of these are distributed over a wide geographical range, possibly due to earlier shipping activities (Gollasch 1996; Lenz et al. 2000). However, the relative transport vector importance is assumed to be regionally different, e.g. according to the local industry. In the Mediterranean Sea most non-indigenous species reported migrated through the Suez Canal. The low

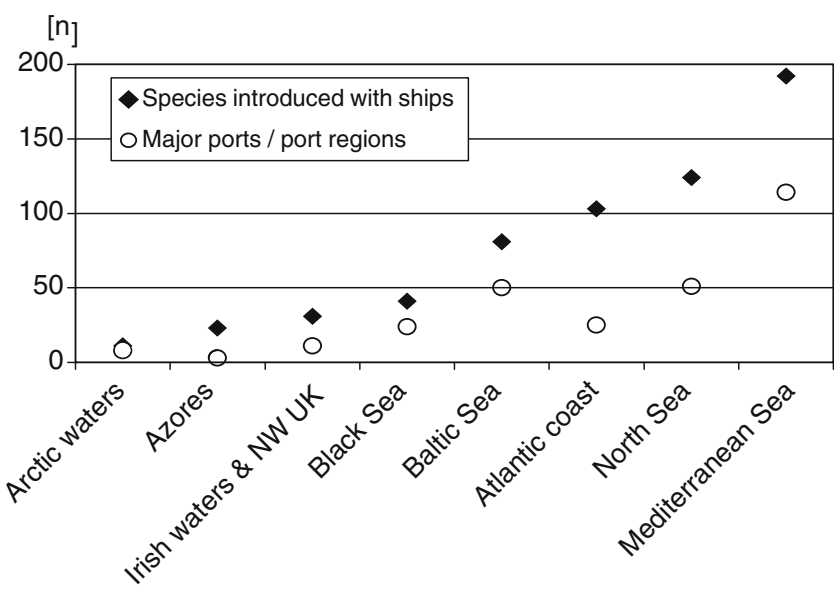

Fig. 3 Ship-mediated species introductions per region according to the number of major ports or port regions

number of non-indigenous species in European Arctic waters is probably due to the comparably lower number of ports accommodating ships in inter-oceanic voyages and less-developed aquaculture facilities here. In many regions the most prominent introduction vectors are shipping, intentional introductions for aquaculture and stocking purposes including target and non-target species, such as fouling organisms on oysters, disease agents and parasites.

As shipping is one of the dominating vectors, the number of major ports and port regions in Europe was assessed according to Aldworth (1999) and the Lloyd's Register-Fairplay (2004). Figure 3 shows the number of ship-mediated (ballast water and hull fouling) species introductions per region according to the number of major ports or port regions. In general, the more are the ports or port regions located within a geographic region the higher is the number of introduced species, thereby indicating the importance of the invasion vector shipping.

The annually increasing number of newly found species in Europe since 1850 was probably caused by the increase in shipping and aquaculture initiatives. Everimproving ship design develops larger and faster ships resulting in more frequent ship arrivals and higher amounts of ballast water being released. Also faster ships result in shorter voyage duration with improved species survival en route. Aquaculture is also an increasing industry and consequently more organisms are imported to facilitate the increasing demand. New species are also under consideration as target taxa for future aquaculture activities. These two most prominent invasion vectors showed an increasing trend over the last 150 years resulting in more species to arrive.

It is interesting to note that 65 species have reached new regions by range expansion (other than the 253 Lessepsian migrants) - a possible indication of a changing climate regime as several of these species are known from warmer climate regions and have now been found in colder waters. Wiltshire (personal communi- 
cation) and Franke and Gutow (2004) stated that several non-indigenous species were newly recorded in the North Sea near Helgoland which are known to have an eastwards distribution limit in the British Channel or are known from the Mediterranean Sea.

Earlier inventories of non-indigenous species in European seas resulted in a far lower number of introduced species. It is assumed that the higher numbers in this publication are because (a) of new arrivals and (b) a larger number of habitats was considered here, i.e. adjacent brackish and freshwater regions as well as navigational waterways of ocean-going ships (i.e. inner estuaries and the Kiel Canal), but have not been included in earlier inventories. According to this inventory 144 established species are recorded from the North Sea and adjacent waters although Reise et al. (1999) only list 81 taxa-not including brackish and freshwater species occurring in waters adjacent to the North Sea. In the Baltic Sea approximately 100 introduced species are known (Olenin et al. 2005). This summary reports 170 introduced species of which 99 are considered established. The higher number compared to the Baltic Sea database is probably due to the inclusion of adjacent waters and new species arrivals since the database was updated last.

Reise et al. (1999) concluded that in the North Sea introduced species are more "additive" without major unwanted impacts. However, nowadays the introduced Pacific oyster C. gigas is spreading in the Wadden Sea and shows a competitive impact on mussel beds of the native blue mussel Mytilus edulis. This is likely due to the recent warm summers supporting the recruitment of the Pacific oyster and also due to the lack of cold winters which allows good recruitment of Mytilus edulis. It is assumed that the current success of $C$. gigas may reverse in case water temperatures change (Diederich 2005). In other European regions devastating effects are reported [e.g. the introduction of the comb jelly Mnemiopsis leidyi in the Black Sea (GESAMP 1997) or the green alga Caulerpa taxifolia in the Mediterranean Sea (Boudouresque et al. 1992)]. However, negative impacts of the above-mentioned species may only be temporary and are also subject to controversial discussion.

Currently a EU-funded project entitled "Delivering Alien Invasive Species Inventories for Europe (DAISIE)" is underway, which includes the objective to prepare a comprehensive inventory of all non-indigenous species known from Europe. The key objective of the project is to create an inventory of non-indigenous species that threaten European terrestrial, freshwater and marine environments. It is expected that this project will result in a more comprehensive inventory of nonindigenous species in European coastal waters, although the focus of the DAISIE project is on species which pose a significant impact whereas the inventory presented here includes all known non-indigenous species whether or not they are known to cause an impact to the European coasts. The geographic coverage of the DAISIE project is more comprehensive than in this account, also including the non-European countries along the southern and eastern Mediterranean Sea. In contrast, this inventory is considered as a subset of the DASIE species inventory due to (a) the limited geographic coverage and (b) the current lack of data on certain regions, which will be addressed until the DAISIE project comes to an end (early 2008).

The vectors shipping, aquaculture and stocking may play a different role in the future as regulatory instruments are either in place or developing to minimize the number of new species introductions. In aquaculture and stocking, the International Council for the Exploration of the Sea (ICES) has updated its Code of Practice for the Introductions and Transfers of Marine Organisms. This instrument provides (voluntary) guidelines to avoid unwanted effects of moved species and unintentional introductions of non-target species (ICES 2003). The International Maritime Organization (IMO), the United Nations specialised agency responsible for, e.g. minimizing pollution from ships, has developed two conventions relevant to biological invasions. One is the International Convention on the Control of Harmful Anti-fouling Systems on Ships. This convention was developed noting the unwanted impact from poisonous antifouling paints based on Tributyl-tin (TBT) in the aquatic environment. Consequently the use of TBT was banned. TBT-free antifouling paints are currently being developed and tested. However, it is suggested that alternative ship coatings may not be as effective, possibly resulting in more species being transported on the ships hull. The second convention prepared by IMO is the International Convention for the Control and Management of Ships' Ballast Water and Sediments. Here, ballast water exchange in open seas is recommended as an intermediate solution to minimize the number of species in transit. As a second step, ballast water treatment will eventually be required knowing that ballast water exchange is of limited efficacy. This convention was adopted in 2004 and is now open for signature by IMO member states. It is hoped that these regulatory instruments will be implemented soon and that by doing so the invasion rate will slow down resulting in an improved protection of European Seas.

As newly found species are usually reported with a time lag due to publishing procedures in scientific journals the number of first records in the current decade will likely increase in the future.

Acknowledgements The author expresses his grateful thanks to a large number of colleagues who contributed to this inventory, the list being too numerous to be mentioned here. Special thanks are expressed to Argyro Zenetos and Nikos Streftaris (Hellenic Centre for Marine Research, Anavissos, Greece) and Matej David (University of Ljubljana, Portoroz, Slovenia) who shared information of other inventories of exotic species in Europe. The author is a contributing partner in the EU funded project Delivering Alien Invasive Species Inventories for Europe (DAISIE). The author acknowledges the support by the MARBEF Network of Excellence "Marine Biodiversity and Ecosystem Functioning" which is funded in the Community's Sixth Framework Programme (contract no. 
GOCE-CT-2003-505446). This publication is contribution number MPS-06002 of MarBEF.

\section{References}

Aldworth P (ed) (1999) Lloyd's maritime atlas of world ports and shipping places, 20th edn. Lloyd's of London Press, Colchester, $156 \mathrm{pp}$

Boudouresque CF, Meinesz A, Verlaque M, Knoepffler-Peguy M (1992) The expansion of the tropical alga Caulerpa taxifolia (Chlorophyta) in the Mediterranean. J Phycol 13:144-145

Carlton JT (1985) Transoceanic and interoceanic dispersal of coastal marine organisms: the biology of ballast water. Oceanogr Mar Biol Annu Rev 23:313-371

Carlton JT (1987) Patterns of transoceanic marine biological invasions in the Pacific Ocean. Bull Mar Sci 41:452-465

CIESM (2005) Atlas of exotic species in the Mediterranean Sea. http://www.ciesm.org/atlas, visited January 2005

Cohen AN, Carlton JT (1995) Biological study: non-indigenous aquatic species in a United States estuary: a case study of the biological invasions of the San Francisco Bay and Delta. US Fisheries and Wildlife and National Sea Grant College Program Report PB96-166525, Springfield, VA, USA, 273 pp

Diederich S (2005) Differential recruitment of introduced Pacific oysters and native mussels at the North Sea coast: coexistence possible? J Sea Res 53:269-281

Eno NC (1996) Non-native species in British waters: effects and controls. Aquat Conserv Mar Freshw Ecosyst 6:215-228

Eno NC, Clark RA, Sanderson WG (1997) Non-native species in British waters: a review and directory. Joint Nature Conservation Committee, Peterborough, $152 \mathrm{pp}$

Franke H-D, Gutow L (2004) Long-term changes in the macrozoobenthos around the rocky island of Helgoland (German Bight, North Sea). Helgoland Mar Res 58:303-310

Galil B, Zenetos A (2002) A sea change-exotics in the eastern Mediterranean Sea. In: Leppäkoski E, Gollasch S, Olenin S (eds) Invasive aquatic species of Europe: distribution, impacts and management. Kluwer Academic Publishers, Dordrecht, 583 pp

GESAMP (1997) Opportunistic settlers and the problem of the ctenophore Mnemiopsis leidyi invasion in the Black Sea. GESAMP Rep Stud 58:1-84

Gollasch S (1996) Untersuchungen des Arteintrages durch den internationalen Schiffsverkehr unter besonderer Berücksichtigung nichtheimischer Arten. Dissertation, University of Hamburg, $314 \mathrm{pp}$
Gollasch S, Mecke R (1996) Eingeschleppte Organismen. In: Lozan JL, Lampe R, Matthäus W, Rachor E, Rumohr H, Westernhagen Hv (eds) Warnsignale aus der Ostsee. Parey Buchverlag, Berlin, pp 146-150

ICES (2003) ICES code of practice on the introductions and transfers of marine organisms, $27 \mathrm{pp}$

Lenz J, Andres H-G, Gollasch S, Dammer M (2000) Einschleppung fremder Organismen in Nord- und Ostsee: Untersuchungen zum ökologischen Gefahrenpotential durch den Schiffsverkehr. UBA Project Water, Umweltbundesamt, Berlin 5, 273 pp

Leppäkoski E (1994) Non-indigenous species in the Baltic Sea. In: Boudouresque CF, Briand F, Nolan C (eds) Introduced species in European coastal waters, CEC Ecosystem Research Report 8, pp 67-75

Leppäkoski E, Olenin S (2000) Non-native species and rates of spread: lessons from the brackish Baltic Sea. Biol Invasions 2:151-163

Lloyd's Register-Fairplay (2004) Ports and terminals guide 2005, published as CD-ROM

Minchin D, Eno NC (2002) Exotics of coastal and inland waters of Ireland and Britain. In: Leppäkoski E, Gollasch S, Olenin S (eds) Invasive aquatic species of Europe: distribution, impacts and management. Kluwer Academic Publishers, Dordrecht, 583 pp

Nehring S (2002) Biological invasions into German waters: an evaluation of the importance of different human-mediated vectors for nonindigenous macrozoobenthic species. In: Leppäkoski E, Gollasch S, Olenin S (eds) Invasive aquatic species of Europe: distribution, impacts and management. Kluwer Academic Publishers, Dordrecht, 583 pp

Olenin S, Daunys D, Dauniene E (eds) (2005) Baltic Sea alien species database. http://www.ku.lt/nemo/mainnemo.html

Olsvik PA (1996) The red king crab, Paralithodes camtschatica (Tilesius 1815), in the Barents Sea: life history and future stock progress. Fauna 49(1):20-33

Reise K, Gollasch S, Wolff WJ (1999) Introduced marine species of the North Sea coasts. Helgoländer Meeresuntersuchungen $52: 219-234$

Sindermann CJ (1992) The introduction of marine species: what the future holds. In: DeVoe R (eds) Proceedings of the conference $\&$ workshop. Introductions and transfers of marine species. Achieving a balance between economic development and resource protection, Session VII, South Carolina Sea Grant Consortium, USA, pp 143-148

Streftaris N, Zenetos A, Papathanassiou E (2005) Globalisation in marine ecosystems: the story of non-indigenous marine species across European seas. Oceanogr Mar Biol 43:419-453 